\title{
Organizational Communication and Teachers' Productivity in Secondary Schools in Ondo State, Nigeria
}

\author{
Adeolu Joshua AYENI (Ph.D.) ${ }^{1 *}$ Oluwatoyin Bolanle AKINOLA, (Ph.D.). ${ }^{2}$ \\ 1. Department of Educational Management, Adekunle Ajasin University, Akungba-Akoko, Nigeria \\ 2. Department of Educational Management, Obafemi Awolowo University, Ile-Ife, Nigeria \\ *ayeniadeolu@yahoo.com olubolakinola2@gmail.com
}

\begin{abstract}
There has been persistent deep concern by stakeholders in the education sector over the perceived inadequacies in the communication approaches and dwindling level of productivity in Nigerian secondary schools. This study therefore examined the efficacy of principals' communication strategies and level of teachers' productivity. It further investigated constraints faced in communication process in secondary schools in Ondo State, Nigeria. Three research questions and one hypothesis guided the study. Descriptive survey research design was adopted. Data were collected using instruments titled "Principals' Communication Strategies and Teachers' Productivity Questionnaire" (PCSTPQ). Multi-stage sampling technique was used to select 60 secondary schools from the three senatorial districts in Ondo State. Participants comprised 60 principals and 1200 teachers. Data were analyzed using frequency count, percentage and Pearson Product Moment Correlation (PPMC) at alpha level of 0.05 . Findings indicated significant relationship between principals' communication strategies and teachers' productivity $(\mathrm{r}-\mathrm{cal}=0.680, \mathrm{p}<0.05)$. The major constraints to communication are: poor internet connection, delay in information processing which often cause delay in decision-making process, and lack of modern communication facilities to enhance teachers' productivity. It is hereby recommended that the government in collaboration with other relevant stakeholders in education should give top priority to the provision of adequate internet, information processing facilities, and build principals' and teachers' capacities in digital knowledge-based pedagogy and communication skills to improve productivity in secondary schools.
\end{abstract}

Keywords: Organization, principals, teachers, communication strategies, productivity.

DOI: $10.7176 / \mathrm{JEP} / 11-17-11$

Publication date:June 30th 2020

\section{Introduction}

The secondary school is a formal organization and a social system made up of a group of educators (principals, teachers) whose knowledge, skills and experience complement each other in various disciplines and working together in a connected structure within and across departments that are coordinated by the top management members (principal, vice principal, and heads of departments) to ensure successful implementation of the school curricula and co-curricular activities in the training of students to achieve educational goals.

Communication is a two-way process of passing ideas, feelings and messages from one person to the other in a manner that limited resources in terms of material, funds, time and energy are used judiciously to achieve the set goals in the organization. The inter-relatedness of the school activities makes communication a matter of top priority and first-line item which serves as vital tool in the process of linking people to achieve a common purpose, by developing thoughtful ideas, sharing information and attaining mutual understanding of the subject matter conveyed between the top management (principal, vice principals) and other members of staff (teachers) in the task of inculcating knowledge, skills and values that will make students achieve educational goals.

According to Ibrahim (2006), the innovation in the process of teaching in the modern period has enhanced the use of sophisticated communication techniques such as teleconference, video-conference and electrical mails, thus reducing the whole world to a global village. In the Nigerian school system, the common methods of communication that are used by principals and teachers in their daily dealings include written instruction, announcement through notices circulated or pasted on boards, internal memoranda, circular letters, bulletins, staff meetings, Parent-Teachers Association meetings, broadcast messages, school committees, files, records, reports, and e-messages.

In the school organization, principals' communication strategies and teachers' productivity are imperative for the achievement of the educational goals. Teachers' are the hubs on which the education system rests upon and their roles cannot be under-estimated if quality education is to be achieved. The principal being the instructional leader is expected to be the driving force for effective curriculum delivery. It is the task of the principal to device appropriate measures to ensure that all the teachers comply with the laid down rules and regulations in the performance of their instructional tasks. This is not to witch-hunt the teachers but to make them committed, self-regulated, goal-oriented, and have high expectations for the learners (Ayeni and Akinfolarin, 2014).

In spite of the awareness of the goals of secondary education by the principals and teachers, the levels of students who obtained five credits and above in subjects including English Language and Mathematics in the West African Senior School Certificate Examinations (WASSCE)) were relatively low and fluctuating between 2016 and 2018, and reflected the following percentages in 2016 (52.97\%), 2017 (59.22\%) and 2018 (49.98\%) in Nigeria (Adenipekun, 2018). Similarly, in Ondo State, the performance levels of students' who obtained five credits and above in subjects including English Language and Mathematics in WASSCE reflected the following percentages in 2014 (24.36\%), 2015 (30.29\%), 2016 (61.64\%), 2017 $(46.17 \%)$ and $47.20 \%$ recorded in 2018 (Ministry of Education, 2018).

The need to improve teachers' productivity in terms of students' academic performance is a cause of concern to the stakeholders in the education sector. This study is therefore important now that the global best practices placed emphasis on the modern trends (digital technology) and communication strategies which enhance research, innovation, creativity, 
networking, knowledge dissemination, skills development, resource coordination and sustainable improvement in teachers' productivity in secondary schools. It is also hoped that the outcome of this study could create more awareness and serves as reference point for educational planners, policy makers, principals, teachers and other relevant stakeholders in the education sector on the need to improve on communication strategies for optimal productivity in secondary schools.

\section{1 Concept of Communication}

Communication is the process of creating, sharing and exchanging ideas, feelings, thoughts and information to make people active, reflective and improve in the performance of their tasks in the organization. The basic functions of teachers rely almost on communication and co-ordination among various levels in the school organizational structure. This stimulates teachers' morale, initiative, networking, quality service delivery and sustainable improvement in the work process towards achieving the educational goals (Udeze, 2004).

The regular sharing of information between principals and teachers concerning educational objectives and curriculum contents improve teachers' competence and productivity. Principals are expected to establish and apply effective communication strategies to stimulate teachers in order to achieve the educational goals. However, the perceived inconsistencies in communication channel, poor networking and gap in interdependence could impede effective coordination of human and material resources, which has perhaps been responsible for ineffective curriculum delivery and the relatively low productivity in many Nigerian secondary schools. Ijaiya (2013) in her study on education and teachers' productivity stated that if teachers fail to measure up in the performance of various assignments, they may be perceived uncooperative and unproductive. This also underscores the need to close communication gap between principals and teachers in order to strengthen collaboration for improved productivity in secondary schools.

\subsection{Principals' Communication Strategies}

Communication is the process whereby one party transmits messages to the other who interprets or internalizes it. This process facilitates influence of one party over the other (Durbin, 2005). Mwankwo (2003) defines communication as an interaction between a minimum of two symbolic systems (persons or groups). Communication serves as a linking process by which parts of a system are tied together. Communication enables people to develop and share knowledge, combine efforts and expand their store of knowledge, technology and culture for the purpose of achieving best practices in service delivery.

The form of communication strategies used in a given school will affect the way people interact, and have impact on the general atmosphere of the school and quality of instruction that students receive through appropriate communication medium which the principals could use to realign and modify the attitude of teachers and students towards achievement of set targets in secondary schools (Muyiera, 2002)..

Effective communication can be achieved through regular meetings where different sections and departments report their progress and discuss the way forward in solving their problems. This can also be achieved through organization's reports which are used to examine the work done, share best practices and keep the staff abreast of innovative approaches that are necessary for the accomplishment of prescribed tasks and goals. Principals can perform regulatory role through network of information, operational manuals, policies, orders/instructions which enable teachers to know exactly what they are expected to do, why, how, when, where and whom they are responsible (Downs, 2009). It is also necessary to specify in clear terms the precautions to be taken when handling the tasks. The information must be clear from semantic problems by explaining various terms used and how they are related to the tasks.

The common patterns of communication in the school system are: principal-staff communication, staff initiated communication, and interactive communication (Ibrahim, 2006). This means that communication goes down, up, and across the organizational lines. Principal-Staff Communication is the downward flow of information from the principal at the top of the school administration to the /teachers (Ake, 2003). The management assumes to know what is best for the school and the staff. Decisions are made at the highest level and passed down through the school's hierarchy. In order to improve the quality of service delivery in the school system, superior-subordinate communication requires that the top management officers must give appropriate guidelines on operational strategies, instructional resources, performance standard and time frame for feedback on tasks performance to achieve the educational goals.

In secondary school system, subordinates (teachers) can also initiate communication process using methods such as memos, minutes, explanations, requests and reports at the lower levels of the school hierarchy and passed information upwards to the chief executive who is the principal. Upward flows of information serves as input upon which decisions or changes in policy are made to enhance the effectiveness of the school. This process facilitates the achievement of the set goals and results in conducive administrative climate in an organization.

Other channels of communication include horizontal communication which is often used among heads of departments or teachers within the same department while the diagonal communication is the process by which the principal occasionally communicate directly with the teacher without passing information through the head of department when there is an urgent task to be performed.

Communication is enhanced through the following means: chain of command through which teachers can minute or report to the principal on any vital issue that needs attention while the grievance procedure enables the subordinate to appeal beyond the authority of the immediate supervisor; grapevine communication, interview, teachers' welfare associations and special meetings might be adopted to discuss certain observed pressing issues between the various levels of authorities in the organization.

\subsection{Principals' Communication Strategies and Teachers' Productivity}

Principals play key role in the management of human and materials resources to achieve educational goals in secondary schools. This could depend largely on the ability of principals to communicate effectively in the process of coordinating teachers' instructional tasks in secondary schools. Redding (2003) described communication as the transfer of information 
from the sender to the receiver with the information being understood by the receiver. On the other hand, productivity is the measuring of the efficiency of the organization or the individual performance to achieve given set of objectives. Productivity measure indicates the rate of growth in capabilities of respective organizations to accomplish and indeed fulfill their mission /goals and ensuring that quality of goods and services meet the expected standard.

Nwachukwu (2006) viewed productivity as the relationship between output of goods and service, and resource inputs (human and materials) which are utilized in the production of goods and services. According to Akinloye (2013), productivity is the degree of efficiency and effectiveness with which an individual contributes to the achievement of set objectives. This implied that an efficient teacher utilizes the available resources optimally to accomplish the tasks set out in the job description/ schedule within the stipulated time.

Productivity in education is the rate at which educational objectives are achieved, putting into consideration, the input, process and output phases of education. In the context of this study, productivity refers to the level of teachers' effectiveness in adherence to the time-table, lesson planning, usage of textbooks, research, usage of instructional materials, students' motivation, classroom management, students' discipline, continuous assessment, and performance feedback.

Ijaiya (2013) in her study on education and teachers' productivity found that principals, teachers' work performance and productivity are determined by effective teaching measured by students' academic performance in examinations, punctuality at school and classes, giving extra lessons to students and contribution to the progress of the school through participation in co-curricular activities such as sports, students' discipline, committee assignment as may be given by the principal. She further stressed that if teachers fail to measure up in these various assignments, they may be perceived uncooperative and unproductive.

Effective communication in an organization strengthens the level of coordination which usually results in high productivity in the organization. Ogunsanya (2003) stated that effective communication bring about efficient task performance and prompt intervention in solving problems in an organization. This implied that there is a positive relationship between communication and workers' behaviour in an organization.

Effective communication in a school system has the intent of influencing behaviour. This is in view of the fact that as people communicate with one another to resolve problems; it is evident that ideas, attitudes and feelings are exchanged and understood. The open school climate promotes positive interaction, high spirit, mutual consideration, trust and innovative best practices that enhance teachers' productivity.

Ogunsanya (2003) stated that for teachers to be highly productive in the school system, the school principal has to be dynamic, showing good examples and treat teachers with dignity, involving them as much as possible in important decisions that may likely affect them in the school. This will motivate them to put in their best in instructional tasks performance and achieve the set educational goals.

Effective communication in a school helps the principal to think out well, generate good ideas, conceive goal-oriented plans, establish sound organization structures, and take good decisions. These also give teachers better understanding of their work and accept the need for innovation in curriculum delivery, which improves the level of productivity in secondary schools. However, the perceived inconsistencies in communication strategies seem to hamper teachers' productivity, which has been a matter of serious concern to stakeholders in education.

\section{The Problem, Research Questions, Hypotheses and Research Method \\ 3.1 Statement of the Problem}

The desire for quality education is generally the concern of stakeholders in the education sector in Nigeria. However, the level of teachers' productivity seems to be dwindling partly due to the perceived inconsistencies and inadequacies in the principals' communication strategies. Communication gaps often occur in a school when there is breakdown in communication and different units of the organization tend to operate in isolation and perhaps in conflict with the other components to the detriment of the overall objectives of the organization. This situation could lead to possible misunderstanding between principal and teachers, frustration of teachers and the school authority, and indiscipline which could reduce the level of teachers' productivity in the school system.

The perceived inadequacies in many principals' communication strategies often cause poor coordination and create gaps in teachers' instructional tasks performance which has been partly attributed to inadequate information concerning the performance of their tasks. This situation could have serious negative implications on curriculum delivery and has perhaps been responsible for the relatively low academic performance of students in the West African Senior School Certificate Examinations (WASSCE) in Nigerian secondary schools. This study therefore intended to investigate the extent to which principals use communication strategies in coordinating teachers' instructional tasks, identify their challenges, and determine the level of productivity in secondary schools in Ondo State, Nigeria.

\subsection{Research Questions}

The following research questions were raised to guide the study.

i. What communication strategies are adopted by principals in secondary schools in Ondo State?

ii. What is the level of teachers' productivity in secondary schools in Ondo State?

iii. What constraints are faced by teachers in communication in secondary schools?

\subsection{Hypotheses}

The following research hypothesis was formulated to guide the study.

$\mathrm{Ho}_{1}$ : There is no significant relationship between principals' communication strategies and

teachers' productivity in secondary schools in Ondo State. 


\subsection{Research Method}

The study adopted the descriptive survey research design. The population comprised of all public secondary school principals and teachers in Ondo State. Multi-stage sampling technique was used to select three (3) Local Government Areas from the three senatorial districts. Twenty (20) secondary schools were randomly selected from each of the 3 Local Government Areas, thus making a total of 60 secondary schools sampled for the study. The respondents consisted of 1200 teachers randomly selected at 20 teachers per school. All the 60 principals of the sampled schools were included in the study.

A self developed questionnaire titled; "Principals' Communication Strategies and Teachers' Productivity Questionnaire" (PCSTPQ) was used to collect data. The instrument elicited information on the components variables of communication strategies and instructional tasks performance. The questionnaire was validated by two experts in the Department of Educational Management, Adekunke Ajasin University, Akungba-Akoko, Ondo State and Test and Measurement Unit, Faculty of Education, Obafemi Awolowo University, Ile-Ife, Nigeria. Test-retest method was adopted for the reliability of the instrument administered in two (2) secondary schools outside the Local Government Areas of the study. Pearson Product Moment Correlation (PPMC) was used to calculate the co-efficient value which yielded 0.82. This indicated the suitability of the research instrument for the study. Two trained research assistants helped to administer the questionnaires on the respondents and ensured that the questionnaires were properly filled and collected on the spot. This method ensured $100 \%$ return rate. Data were analyzed using frequency counts, mean score and Pearson Product Moment Correlation at alpha level of 0.05 .

\section{Results}

The results and discussions of data analyses are presented in two parts based on the research questions and hypothesis that were formulated for the study. Data collected on research questions were analyzed using frequency count and percentage while hypotheses were tested at 0.05 level of significance using Pearson Product Moment Correlation (PPMC). The results are presented in tables $1-4$.

4.1. What communication strategies are adopted by principals in secondary schools?

The analysis of data in table 1 and figure 1, on communication strategies that are adopted by principals reflected the following percentage level of effectiveness: e-messaging (38.7\%), circular letters $(77.3 \%)$, suggestion box $(60.7 \%)$, notice boards $(56.7 \%)$, seminars/workshops $(47.4 \%)$ internal memos $(60.0 \%)$, staff meetings $(68.7 \%)$, workers' association (66.6\%), bulletin/newsletter (57.3\%) and text messages (75.7\%). These were reflected in percentage points of strongly agree and agree responses combined.

Table 1: Principals' Communication Strategies in Secondary Schools

\begin{tabular}{|c|c|c|c|c|}
\hline $\mathrm{S} / \mathrm{N} \quad$ Items & $\begin{array}{c}\text { SA } \\
\text { Freq. } \\
\%\end{array}$ & $\begin{array}{c}\text { A } \\
\text { Freq. } \\
\%\end{array}$ & $\begin{array}{c}\text { FA } \\
\text { Freq. } \\
\%\end{array}$ & $\begin{array}{c}\mathrm{D} \\
\text { Freq. } \\
\%\end{array}$ \\
\hline 1. Principals use e-mails. & $\begin{array}{l}248 \\
(20.7)\end{array}$ & $\begin{array}{l}216 \\
(18.0)\end{array}$ & $\begin{array}{l}400 \\
(33.3)\end{array}$ & $\begin{array}{l}336 \\
(28.0)\end{array}$ \\
\hline 2. Principals use circular letters and notice boards. & $\begin{array}{l}432 \\
(36.0)\end{array}$ & $\begin{array}{l}496 \\
(41.3)\end{array}$ & $\begin{array}{l}202 \\
(16.8)\end{array}$ & $\begin{array}{l}70 \\
(5.8)\end{array}$ \\
\hline 3. Principals use suggestion boxes. & $\begin{array}{l}336 \\
(28.0)\end{array}$ & $\begin{array}{l}392 \\
(32.7)\end{array}$ & $\begin{array}{l}272 \\
(22.7)\end{array}$ & $\begin{array}{l}200 \\
(16.7)\end{array}$ \\
\hline 4. Principals use radio/television announcements. & $\begin{array}{l}368 \\
(30.7)\end{array}$ & $\begin{array}{l}312 \\
(26.0)\end{array}$ & $\begin{array}{l}352 \\
(29.3)\end{array}$ & $\begin{array}{l}168 \\
(14.0)\end{array}$ \\
\hline 5. Principals use seminars/workshops. & $\begin{array}{l}193 \\
(16.1)\end{array}$ & $\begin{array}{l}376 \\
(31.3)\end{array}$ & $\begin{array}{l}264 \\
(22.0)\end{array}$ & $\begin{array}{l}367 \\
(30.6)\end{array}$ \\
\hline 6. Principals use internal memos. & $\begin{array}{l}375 \\
(31.3)\end{array}$ & $\begin{array}{l}344 \\
(28.7)\end{array}$ & $\begin{array}{l}356 \\
(29.7)\end{array}$ & $\begin{array}{l}125 \\
(10.4)\end{array}$ \\
\hline 7. Principals use staff meetings. & $\begin{array}{l}440 \\
(36.7)\end{array}$ & $\begin{array}{l}384 \\
(32.0)\end{array}$ & $\begin{array}{l}255 \\
(21.3)\end{array}$ & $\begin{array}{l}121 \\
(10.1)\end{array}$ \\
\hline 8 Principals use workers' associations. & $\begin{array}{l}343 \\
(28.6)\end{array}$ & $\begin{array}{l}456 \\
(38.0)\end{array}$ & $\begin{array}{l}287 \\
(23.9)\end{array}$ & $\begin{array}{l}114 \\
(9.5)\end{array}$ \\
\hline 9. Principals use bulletin/newsletters. & $\begin{array}{l}328 \\
(27.3)\end{array}$ & $\begin{array}{l}360 \\
(30.0)\end{array}$ & $\begin{array}{l}286 \\
(23.8)\end{array}$ & $\begin{array}{l}226 \\
(18.8)\end{array}$ \\
\hline 10. Principals text messages. & $\begin{array}{l}567 \\
(47.3)\end{array}$ & $\begin{array}{l}341 \\
(28.4)\end{array}$ & $\begin{array}{l}188 \\
(15.7)\end{array}$ & $104(8.7)$ \\
\hline
\end{tabular}




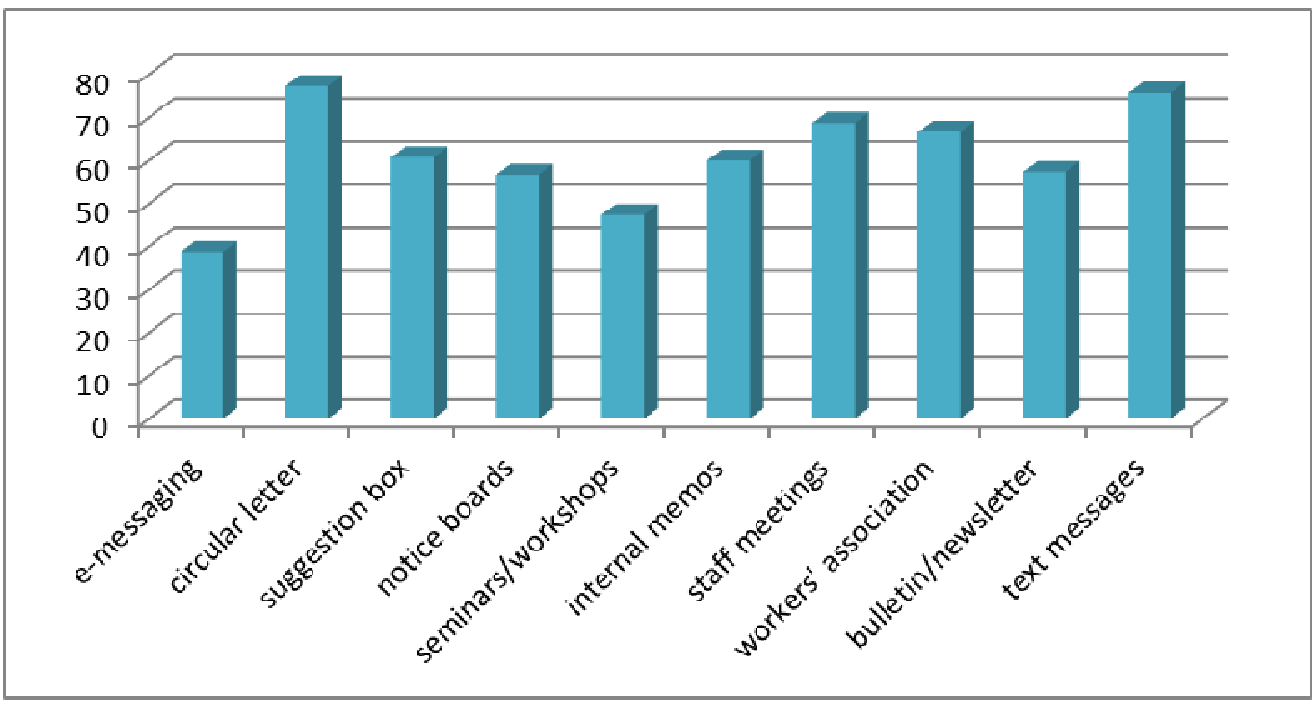

Figure 1: Bar Chart of Principals' Communication Strategies

4.2 What is the level of teachers' instructional tasks performance in secondary schools?

The analysis of data in table 2 and figure 2 indicated that majority of teachers were effective in instructional tasks performance as reflected in the following percentage points: adherence to time-table (71.7\%), lesson planning (73.3\%), usage of prescribed textbooks (73.3\%), engaged in research (56.7\%), instructional materials (46.7\%), students' motivation (50.0\%), classroom management (43.3\%), students' discipline (46.6\%) continuous assessment $(51.6 \%)$ and performance feedback $(61.7 \%)$. These were reflected in percentage points of strongly agree and agree responses combined.

Table 2: Teachers' Productivity in Secondary Schools

\begin{tabular}{|c|c|c|c|c|}
\hline $\mathrm{S} / \mathrm{N} \quad$ Items & $\begin{array}{c}\text { SA } \\
\text { Freq. } \\
\%\end{array}$ & $\begin{array}{c}\text { A } \\
\text { Freq. } \\
\%\end{array}$ & $\begin{array}{c}\text { FA } \\
\text { Freq. } \\
\%\end{array}$ & $\begin{array}{c}\mathrm{D} \\
\text { Freq. } \\
\%\end{array}$ \\
\hline 1. Teachers adhered strictly to the school time-table. & $\begin{array}{l}18 \\
(30.0)\end{array}$ & $\begin{array}{l}25 \\
(41.7)\end{array}$ & $\begin{array}{l}12 \\
(20.0)\end{array}$ & $\begin{array}{l}5 \\
(8.3)\end{array}$ \\
\hline 2. Teachers prepare lesson plan according to syllabi. & $\begin{array}{l}21 \\
(35.0)\end{array}$ & $\begin{array}{l}23 \\
(38.3)\end{array}$ & $\begin{array}{l}13 \\
(21.7)\end{array}$ & $\begin{array}{l}3 \\
(5.0)\end{array}$ \\
\hline 3. Teachers use prescribed textbooks adequately. & $\begin{array}{l}18 \\
(30.0)\end{array}$ & $\begin{array}{l}26 \\
(43.3)\end{array}$ & $\begin{array}{l}12 \\
(20.0)\end{array}$ & $\begin{array}{l}4 \\
(6.7)\end{array}$ \\
\hline 4. Teachers engage in research to improve teaching. & $\begin{array}{l}15 \\
(25.0)\end{array}$ & $\begin{array}{l}19 \\
(31.7)\end{array}$ & $\begin{array}{l}18 \\
(30.0)\end{array}$ & $\begin{array}{l}8 \\
(13.3)\end{array}$ \\
\hline 5.. Teachers use instructional materials effectively. & $\begin{array}{l}13 \\
(21.7)\end{array}$ & $\begin{array}{l}15 \\
(25.0)\end{array}$ & $\begin{array}{l}17 \\
(28.3)\end{array}$ & $\begin{array}{l}15 \\
(25.0)\end{array}$ \\
\hline 6. Teachers adequately motivate students' learning. & $\begin{array}{l}13 \\
(21.7)\end{array}$ & $\begin{array}{l}17 \\
(28.3)\end{array}$ & $\begin{array}{l}23 \\
(38.3)\end{array}$ & $\begin{array}{l}7 \\
(11.7)\end{array}$ \\
\hline 7. Teachers are effective in classroom management. & $\begin{array}{l}12 \\
(20.0)\end{array}$ & $\begin{array}{l}14 \\
(23.3)\end{array}$ & $\begin{array}{l}26 \\
(43.3)\end{array}$ & $\begin{array}{l}8 \\
(13.3)\end{array}$ \\
\hline 8. Teachers enforce discipline based on school rules. & $\begin{array}{l}14 \\
(23.3)\end{array}$ & $\begin{array}{l}14 \\
(23.3)\end{array}$ & $\begin{array}{l}22 \\
(36.7)\end{array}$ & $\begin{array}{l}10 \\
(16.7)\end{array}$ \\
\hline $\begin{array}{l}\text { 9. Teachers conduct continuous assessment } \\
\text { regularly. }\end{array}$ & $\begin{array}{l}14 \\
(23.3)\end{array}$ & $\begin{array}{l}17 \\
(28.3)\end{array}$ & $\begin{array}{l}21 \\
(35.0)\end{array}$ & $\begin{array}{l}8 \\
(13.3)\end{array}$ \\
\hline $\begin{array}{l}\text { 10.Teachers use feedback to assess students' } \\
\text { performance. }\end{array}$ & $\begin{array}{l}16 \\
(26.7)\end{array}$ & $\begin{array}{l}21 \\
(35.0)\end{array}$ & $\begin{array}{l}17 \\
(28.3)\end{array}$ & $\begin{array}{l}6 \\
(10.0)\end{array}$ \\
\hline
\end{tabular}




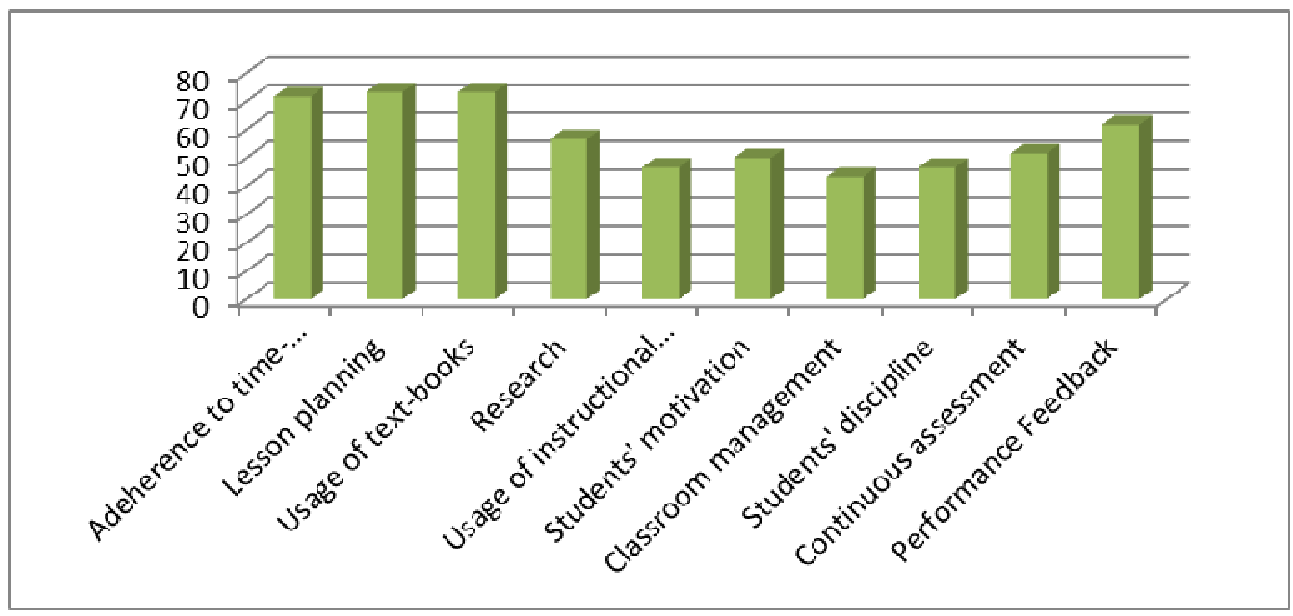

Figure 2: Bar Chart of Teachers' Productivity

4.3 What constraints are faced by teachers in communication in secondary schools?

The analysis of data in table 3 and figure 3 on constraints faced by teachers in communication reflected the following percentage points: poor internet connection $(86.8 \%)$, delay in information processing $(62.3 \%)$, inconsistent communication $(61.3 \%)$, delay in decision making $(47.1 \%)$, unfriendly communication language $(38.3 \%)$, inability to decode messages $(38.0 \%)$, delay reportage $(61.0 \%)$, poor relationship $(44.0 \%)$, lack of facilities maintenance $(67.8 \%)$ and lack of maintenance funds $(73.3 \%)$. These were reflected in percentage points of strongly agree and agree responses combined.

Table 3: Constraints faced by Teachers in Communication in Secondary Schools

\begin{tabular}{|c|c|c|c|c|}
\hline $\mathrm{S} / \mathrm{N} \quad$ Items & $\begin{array}{c}\text { SA } \\
\text { Freq. } \\
\%\end{array}$ & $\begin{array}{c}\text { A } \\
\text { Freq. } \\
\%\end{array}$ & $\begin{array}{c}\text { FA } \\
\text { Freq. } \\
\%\end{array}$ & $\begin{array}{c}\mathrm{D} \\
\text { Freq. } \\
\%\end{array}$ \\
\hline 1. Poor internet connection impedes communication. & $\begin{array}{l}518 \\
(43.2)\end{array}$ & $\begin{array}{l}523 \\
(43.6)\end{array}$ & $\begin{array}{l}129 \\
(10.7)\end{array}$ & $\begin{array}{l}30 \\
(2.5)\end{array}$ \\
\hline 2. Delay in information processing. & $\begin{array}{l}287 \\
(23.9)\end{array}$ & $\begin{array}{l}461 \\
(38.4)\end{array}$ & $\begin{array}{l}266 \\
(22.2)\end{array}$ & $\begin{array}{l}186 \\
(15.5)\end{array}$ \\
\hline 3. Inconsistency in channel of communication. & $\begin{array}{l}365 \\
(30.4)\end{array}$ & $\begin{array}{l}371 \\
(30.9)\end{array}$ & $\begin{array}{l}243 \\
(20.3)\end{array}$ & $\begin{array}{l}221 \\
(18.4)\end{array}$ \\
\hline 4. Delay in decision-making process. & $\begin{array}{l}224 \\
(18.7)\end{array}$ & $\begin{array}{l}341 \\
(28.4)\end{array}$ & $\begin{array}{l}432 \\
(36.0)\end{array}$ & $\begin{array}{l}203 \\
(16.9)\end{array}$ \\
\hline 5. Unfriendly communication language. & $\begin{array}{l}216 \\
(18.0)\end{array}$ & $\begin{array}{l}243 \\
(20.3)\end{array}$ & $\begin{array}{l}310 \\
(25.8)\end{array}$ & $\begin{array}{l}431 \\
(35.9)\end{array}$ \\
\hline 6. Inability to decode messages. & $\begin{array}{l}192 \\
(16.0)\end{array}$ & $\begin{array}{l}264 \\
(22.0)\end{array}$ & $\begin{array}{l}353 \\
(29.4)\end{array}$ & $\begin{array}{l}391 \\
(32.6)\end{array}$ \\
\hline 7. Late receipt of circulars and reports. & $\begin{array}{l}360 \\
(30.0)\end{array}$ & $\begin{array}{l}372 \\
(31.0)\end{array}$ & $\begin{array}{l}246 \\
(20.5)\end{array}$ & $\begin{array}{l}222 \\
(18.5)\end{array}$ \\
\hline 8. Poor working relationship. & $\begin{array}{l}232 \\
(19.3)\end{array}$ & $\begin{array}{l}296 \\
(24.7)\end{array}$ & $\begin{array}{l}200 \\
(16.7)\end{array}$ & $\begin{array}{l}375 \\
(31.3)\end{array}$ \\
\hline 9. Lack of maintenance of communication facilities. & $\begin{array}{l}438 \\
(36.5)\end{array}$ & $\begin{array}{l}376 \\
(31.3)\end{array}$ & $\begin{array}{l}235 \\
(19.6)\end{array}$ & $\begin{array}{l}151 \\
(12.6)\end{array}$ \\
\hline 10. Lack of funds for maintenance of facilities. & $\begin{array}{l}552 \\
(46.0)\end{array}$ & $\begin{array}{l}328 \\
(27.3)\end{array}$ & $\begin{array}{l}200 \\
(16.7)\end{array}$ & $\begin{array}{l}120 \\
(10.0)\end{array}$ \\
\hline
\end{tabular}




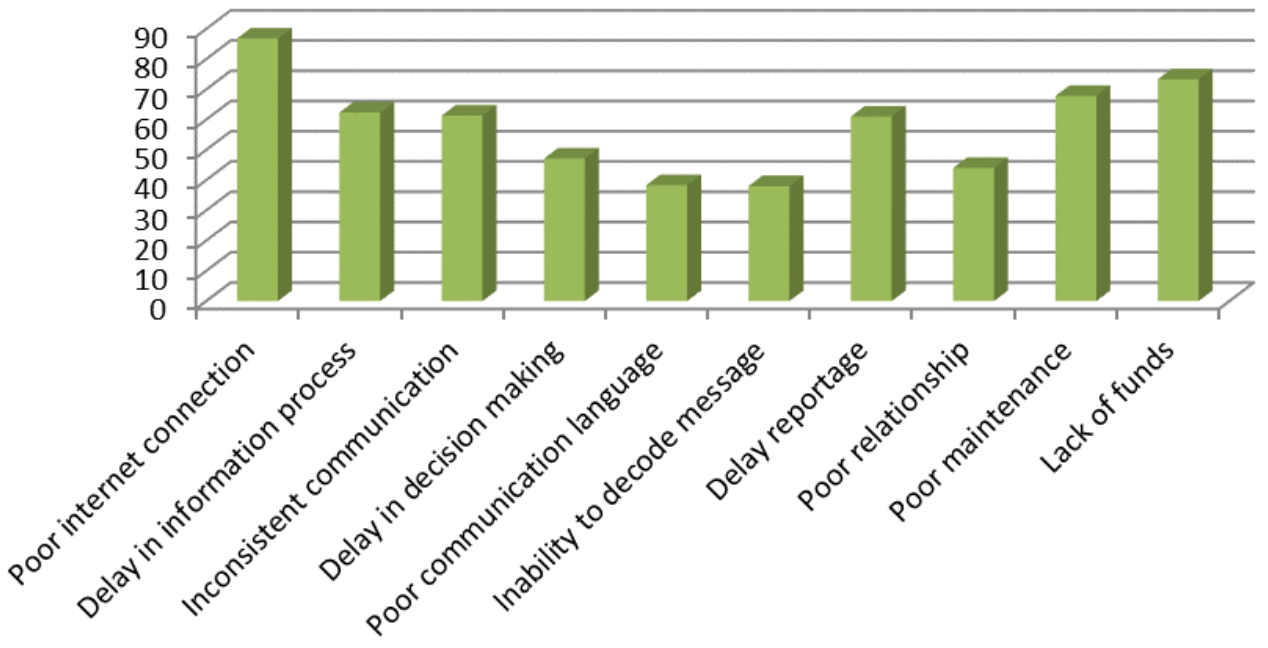

Figure 3: Bar Chart of Teachers' Communication Constraints

4.4 Relationship between principals' communication strategies and teachers' instructional task performance in secondary schools

Hypothesis one was tested by correlating data collected from 1200 teachers on principals' communication strategies and teachers' productivity in 60 sampled secondary schools, using Pearson Product Moment Correlation (PPMC) at alpha level of 0.05 . The result is presented in table 4 .

Table 4: Relationship between Principals' Communication Strategies and Teachers' Productivity

\begin{tabular}{lccccc}
\multicolumn{1}{c}{ Variable } & $\mathrm{N}$ & Mean & SD & R & Sig. \\
\hline $\begin{array}{l}\text { Principals' } \\
\begin{array}{l}\text { Communication } \\
\text { Strategies }\end{array}\end{array}$ & 60 & 27.5883 & 9.67782 & & \\
& & & & 0.680 & 0.001. \\
Teachers' Productivity & 60 & 27.0833 & 9.30335 & & \\
\hline $\boldsymbol{P}<0.05$ & & & & \\
\hline
\end{tabular}

\section{$P<0.05$}

The result presented on table 4 above revealed that the calculated r-value $(0.680)$ was greater than the critical-value $(0.001)$ at $\mathrm{p}<0.05$ is significant. Hence, the null hypothesis $(\mathrm{Ho})$ of no significant relationship is rejected. This implied that there is a significant relationship between principals' communication strategies and teachers' productivity in secondary schools.

\section{Discussions}

Results obtained on teachers' ratings (strongly agree and agree combined) on principals' communication strategies in table 1 , indicated that the level of principals' effectiveness were $60 \%$ and above in the use of the following communication strategies: circular letters $(77.3 \%)$, text messages $(75.7 \%)$, staff meetings $(68.7 \%)$, workers' association $(66.6 \%)$, suggestion box $(60.7 \%)$ and internal memos $(60.0 \%)$. The results also reflected the level of principals' effectiveness in notice boards $(56.7 \%)$ and bulletin/newsletter $(57.3 \%$ ) while $47.4 \%$ showed strong commitment to seminars/workshops and $38.7 \%$ effectively utilized e-mails.

It could be deduced from the results on data analysis above, that most principals placed high premium on the use of communication strategies as vital tools and driving force in creating enabling working environment and coordinating teachers' instructional tasks performance to achieve the desired results in secondary schools. This is in line with Anya and Ezekie (2019) who found that effective communication channels foster interpersonal relationships, cross-fertilization of ideas, problem-solving and the achievement of educational goals in secondary schools in River State, Nigeria. However, the $47.4 \%$ recorded in seminars/workshops implied that principals still need to strive harder in the task of building teachers' capacity for optimal performance.

The findings on principals' ratings of teachers' productivity in table 2 and figure 2 indicated that teachers were effective in adherence to time-table $(71.7 \%)$, lesson planning $(73.3 \%)$, usage of prescribed textbooks $(73.3 \%)$, research $(56.7 \%)$, students' motivation $(50.0 \%)$, continuous assessment $(51.6 \%)$ and performance feedback $(61.7 \%)$. It could be deduced that majority of the teachers responded positively to appropriate use of communication strategies to improve tasks performance. However, the level of teachers' effectiveness was below average in the use of instructional materials (46.7\%), classroom management (43.3\%) and students' discipline (46.6\%). The relatively low level of teachers' effectiveness in these three key aspects of instructional tasks could have negative impact on students' academic performance in secondary schools.

The result of data analysis on hypothesis one in table 4 showed that there is a significant relationship between principals' communication strategies and teachers' productivity ( $\mathrm{r}-\mathrm{cal}=0.680>\mathrm{r}$-crit $=0.001, \mathrm{p}<0.05$ ). This implied that most of the principals were effective in the use of communication strategies which enhance teachers' productivity as shown on table 1 , 
which indicated teachers' adherence to time-table (71.7\%), lesson planning $(73.3 \%)$, usage of prescribed textbooks $(73.3 \%)$, research $(56.7 \%)$, students' motivation $(50.0 \%)$, continuous assessment $(51.6 \%)$ and performance feedback $(61.7 \%)$ which serve as driving force and contribute largely to teachers' productivity. This is in agreement with Mgbodile (2004) who found that effective communication by principals enhance teachers' job awareness, involvement and performance in the school organization.

The viewpoints expressed by teachers indicated that the major constraints in communication which often hinder teachers' productivity are reflected in table 3 and figure 3 as follows: poor internet connection $(86.8 \%)$, delay in information processing $(62.3 \%)$, inconsistent communication $(61.3 \%)$, lack of facilities maintenance $(67.8 \%)$ and lack of maintenance funds $(73.3 \%)$. Also, only $47.4 \%$ of the principals showed strong commitment to seminars/workshops on table 1 , which implied low capacity building of teachers in secondary schools.

The identified deficiencies constituted impediments to communication and would no doubt demoralize teachers and could cause setback in the implementation of the curriculum. These situations are likely to be responsible for the relatively low productivity recorded on academic performance of students who obtained credit level passes in five subjects including English Language and Mathematics in the West African Senior School Certificate Examinations between 2016 and 2018 , which reflected the following percentages in 2016 (52.97\%), 2017 (59.22\%) and 2018 (49.98\%) in Nigeria (Adenipekun, 2018).

\subsection{Conclusion}

The findings showed that most of the principals are effective in the use of communication strategies, which also have significant effect on teachers' productivity. However, poor internet connection, inadequate communication facilities, poor maintenance of communication facilities and low capacity development delay information processing and decision-making process, which constitute impediment to effective communication and productivity in secondary schools.

\subsection{Recommendations}

Based on the findings of this study, the following recommendations are made:

i. The Government and relevant stakeholders should prioritize and provide adequate internet, computer accessories and other information processing facilities to improve communication process and productivity in every secondary school.

ii. The Government should provide adequate funds for principals to carry out regular maintenance of communication facilities and provide necessary materials for effective dissemination of information/curriculum content-knowledge in secondary schools.

iii. The Ministry of Education should organize seminars and workshops to educate and upgrade teachers' capacities in digital knowledge-based pedagogy and communication skills to improve principals' coordination competence and teachers' productivity in secondary schools.

iv. Principals should collaborate with relevant stakeholders to organize periodic in-house seminars/workshops for teachers to improve their capacities in the use of interactive communication facilities to enhance the quality of education delivery in secondary schools.

\section{References}

Adenipekun, O. (2018, July, 5). WAEC releases 2018 May/June WASSCE result, says there's decline in pass rate. The Punch, p.14.

Ake, O. H. (2003), Agricultural communication principles and practice. Umuahia: Lamb House Publishers.

Akinloye, G. M.(2013). Teacher demographic and behavioural indicators as correlates of student learning outcomes in secondary schools in Southwest, $\quad$ Nigeria (Unpublished PhD Thesis). University of Ibadan, Ibadan, Nigeria.

Anya, E. C., \& Ezekie, A. I. A. (2019). Communication: A tool for effective secondary education management in Nigeria. International Journal of Education and Evaluation, 5(6), 61-75.

Ayeni, A. J. \& Akinfolarin, C.A. (2014). Assessing principals' coordinating and controlling strategies for effective teaching and quality learning outcome in secondary schools in Ondo State, Nigeria. International Journal of Learning, Teaching and Educational Research, 7(1), 181

Brannon, T.S. (2010). The Effects of classroom management beliefs/ideologies on student academic success. Dissertation completed at California State University. 1 - 97.

Downs, V. F. (2009). On the definition of feedback. Behavioural Science, 28(1), 4-13.

Durbin, N. (2005), Communication in business. London: Longman Group Limited.

Ibrahim, T. (2006). How leadership influences student learning (Learning from Leadership Project Executive Summary). New York: The Wallace Foundation.

Ijaiya, N. Y. S. (2013). Belief systems of secondary school principals and vice principals about productivity of teachers in Ilorin Metropolis, Kwara State.

Mgbodile, T. (2004). Fundamentals of educational administration and planning. Enugu: Magnet Business Enterprise.

Ministry of Education. (2018). Analysis of academic achievement in senior school certificate examinations. Department of Planning, Research and Statistics, Akure, Ondo State.

Nwachukwu, C. C. (2006). Management theory and practice. Onitsha: Africana - FEB Publishers.

Ogunsanya, N. Z. (2003). Introduction to business data processing, (2nd ed). Tokyo: McGregor- hill Book Company. 
Redding, P. S. (2003). The learner centered curriculum. Cambridge: Cambridge University Press.

Udeze, D. A. (2004). Educating the reflective practitioner. Toward a new design for teaching and learning in the professions. San Francisco: Jossey-Bass. 